\title{
ANALYSIS OF PROBLEMS WITH DRY FERMENTATION PROCESS FOR BIOGAS PRODUCTION
}

\author{
Peter PILÁT ${ }^{1)}$, Marek PATSCH ${ }^{2)}$, Jozef JANDAČKA ${ }^{3)}$
}

\begin{abstract}
The technology of dry anaerobic fermentation is still meeting with some scepticism, and therefore in most biogas plants are used wet fermentation technology. Fermentation process would be not complete without an optimal controlled condition: dry matter content, density, $\mathrm{pH}$, and in particular the reaction temperature. If is distrust of dry fermentation eligible it was on the workplace of the Department of Power Engineering at University of Zilina built an experimental small-scale biogas station that allows analysis of optimal parameters of the dry anaerobic fermentation, in particular, however, affect the reaction temperature on yield and quality of biogas.
\end{abstract}

\section{INTRODUCTION}

Dry fermentation is a single-stage process in which all the degradation processes such as hydrolysis, acid formation, acetic acid fermentation and methane production, taking place in one reactor. In agriculture, dry fermentation occurs rarely and is used only there, where is not possible the material with dry matter content of 20 to $60 \%$ wet easily processed. Therefore, to dry technology, there is some mistrust and wet fermentation applications to significantly outweigh the dry. Most of the biogas plants are built near animals farms, where the wastes containing less than $20 \%$ of dry matters. On the other hand, dry fermentation opens new opportunities for agriculture. Rise no waste, which must be expensively disposed of, and vice versa is possible to obtain finished products such as electricity, heat and fertilizer. In order to assess how much distrust of the dry technology entitled, under the scientific project č.1/0258/09 "Optimization of fermentation reactor for dry fermentation", which is realized with financial support from the Scientific Grant Agency (VEGA) of Ministry of Education and SAV (Slovak academy of Sciences') on the workplace of the Department of Power Engineering at University of Zilina was built an experimental small-scale biogas station. Our aim is to measure the impact of fermentation temperature inside the fermentation processes in biogas production in order to achieve maximum yield of high-quality biogas.

\footnotetext{
${ }^{1}$ Ing. Peter Pilát, email: peter.pilat@fstroj.uniza.sk

2) Ing. Marek Patsch, email: marek. patsch@fstroj.uniza.sk

3) prof. Ing. Jozef Jandačka, Ph.D., email: Jozef.jandacka@ fstroj.uniza.sk

Katedra energetickej techniky, Strojnícka fakulta ŽU v Žiline

Univerzitná 8215/1, 01026 Žilina, tel.: +421 415132851
} 


\section{EXPERIMENTAL FERMENTATION REACTORS}

Experimental fermentation reactors have a rectangular shape. Internal dimensions of the bottom fermentation reactors are $800 \times 800 \mathrm{~mm}$ and $694 \mathrm{~mm}$ height. This gives an internal volume about 0.44 cubic meters. Within this space is placed in processed material. To ensure uniform heating of the substrate throughout the fermentation reactor is between the inner and outer coat designed guide rising helix. This helix will ensure smooth flow of heating water across the walls of the fermentation reactor. This should ensure a uniform temperature throughout the fermentation reactor in water coat and thus suitable temperature conditions for the fermentation process. The input heat power is measured by calorimetric method, where the input and output temperature of the reactor was measured by probes PT100 and flow by flow meter Yokogawa.

\section{FULFILLMENT OF FERMENTATION REACTORS}

At filling of the fermentation reactor is necessary to achieve the optimal structure of the volume of the processed substrate, respectively its density. Suitable range is 600 to $800 \mathrm{~kg} \cdot \mathrm{m}^{-3}$. In the performance of maize silage of $31 \mathrm{March} 2011$ density of corn silage fermentation in both reactors reached about $625 \mathrm{kgm}^{-3}$. Each fermentation reactor was filled with about $275 \mathrm{~kg}$ of corn silage.

\section{THE DRY MATTER CONTENT IN THE TREATED SUBSTRATE}

If necessary, adjusting the bulk structure of the substrate, is possible to use straw or mash. By volume increasing is avoiding creation of inhibitors, which negatively affect on microorganism (e.g. ammonium). Volume increase is also important to create space for ventilation of the processed biogas substrate and its accumulation in the upper part of the fermentation reactor. Bulk structure has an impact on biological processes in depth profile of the processed substrate. Optimum dry matter usually varies depending on the substrate to be processed between 30 to $35 \%$. Humidity, respectively dry matter content of corn silage was determined by drying Libra RADWAG WPS 50SX. Measured moisture content of corn silage was $65.79 \%$, it means dry matter content was $34.21 \%$. Because corn silage contains no methane bacteria 6th April 2011 in each fermentation reactor were added about 25 litres of slurry, which was prepared by mixing fresh cow manure from RD Višňové, in warm water. After filling both fermentation reactors were sealed lids, and thus began the fermentation process.

\section{Chemical anAlysis of CORn SILAge}

For the operation of fermentation reactors is needed correct ratio of nitrogen $(\mathrm{N})$ and phosphorus $(P)$ to organic matter. The balance of biomass production is given the necessary balance of nutrients such as COD (chemical oxygen demand): $\mathrm{N}$ : $\mathrm{P}$ ranging from 300 to 500: 6.7: 1. For substrates of natural origin is a sufficient amount of nutrient. Important in terms of biogas production is the ratio of carbon and nitrogen, which would be optimal in the range of C: $N=20$ to 35 (40): 1. If this ratio is high, there is a deficiency of nitrogen in low ratio is considerably produces ammonia, which is toxic at higher concentrations for anaerobic bacteria, especially methane bacteria.

To determine the amount of those conditions were necessary to carry out chemical analysis of corn silage. Chemical analysis carried out by Štátny geologický ústav Dionýza 
Štúra, accredited testing laboratory in Spišská Nová Ves. Results of chemical analysis of corn silage indicated in Table 1. Chemical oxygen demand was not analyzed. Regarding the ratio of nitrogen and phosphorus, its value is 0.6 . The recommended value for this ratio of 6.7 is about 10 -times higher. The ratio of carbon and nitrogen is value about 59 . Even in this case, the recommended value of ratio exceeded. Deficiency of nitrogen in corn silage was eliminated by adding of manure to the corn silage. By this is value of C: $\mathrm{N}$ ratio closer to recommended ratio.

\section{START OF THE FERMENTATION REACTOR HEATING}

Given to the conditions in the laboratory areas associated with high dust levels due to repair wiring fault, it was not possible to run an experimental biogas plant at mesophilic conditions. Temperatures inside the reactor correspond to psychrophilic conditions (15$20{ }^{\circ} \mathrm{C}$ ). On $3^{\text {rd }}$ may 2011 started heating of both fermentation reactors. In the secondary circuit through a thermostatic heater kept the temperature about $35{ }^{\circ} \mathrm{C}$. Running of temperatures during fermentation and fermentation production in both reactors is shown in Figure 1, respectively. Figure 2

Table 1: Chemical analysis of corn silage

\begin{tabular}{|l|l|l|l|}
\hline $\begin{array}{l}\text { The original condition of the sample } \\
\text { (containing water) }\end{array}$ & anhydrous samples \\
\hline Parameter & Contents [\%] & Parameter & Contents [\%] \\
\hline Total water $\mathrm{W}(r)$ & 64,4 & Phosphorus $\mathrm{P}(\mathrm{d})$ & 1,36 \\
\hline Ash $\mathrm{A}(\mathrm{r})$ & 1,10 & Ash $\mathrm{A}(\mathrm{d})$ & 0,03 \\
\hline Total sulfur S(r) & 0,03 & Total sulfur S(d) & 0,03 \\
\hline Carbon $\mathrm{C}(\mathrm{r})$ & 17,3 & Carbon $\mathrm{C}(\mathrm{d})$ & 48,5 \\
\hline Hydrogen $\mathrm{H}(r)$ & 2,28 & Hydrogen $\mathrm{H}(\mathrm{d})$ & 6,42 \\
\hline Nitrogen $\mathrm{N}(r)$ & 0,29 & Nitrogen $\mathrm{N}(\mathrm{d})$ & 0,82 \\
\hline
\end{tabular}

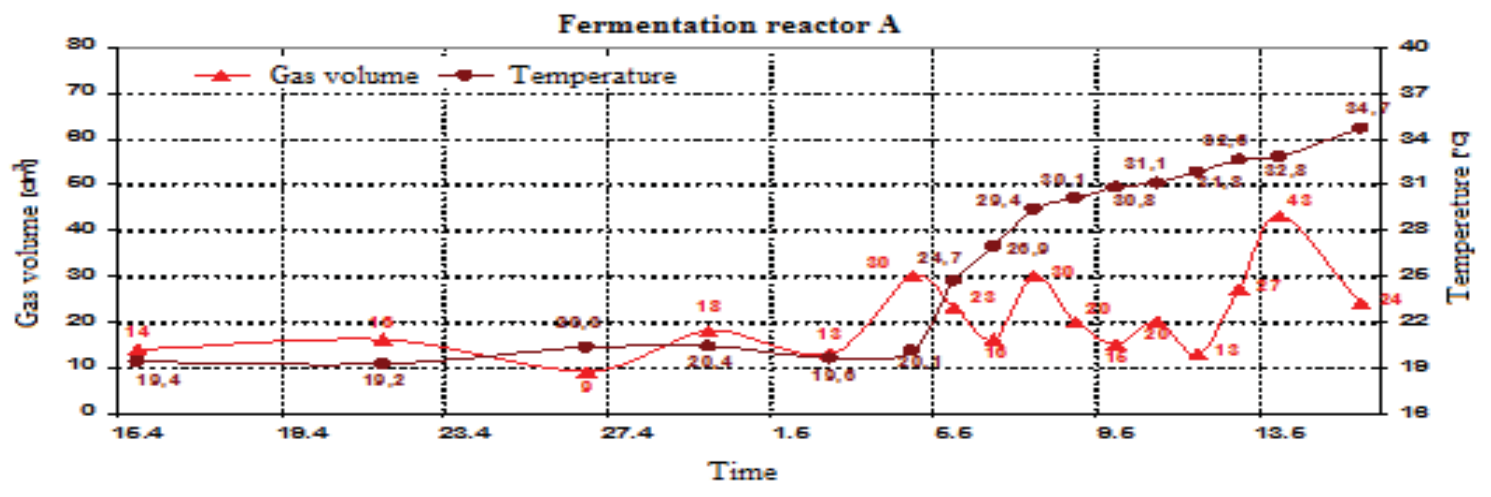

Figure 1: Course of temperature during fermentation and gas production in the reactor $\mathbf{A}$ 


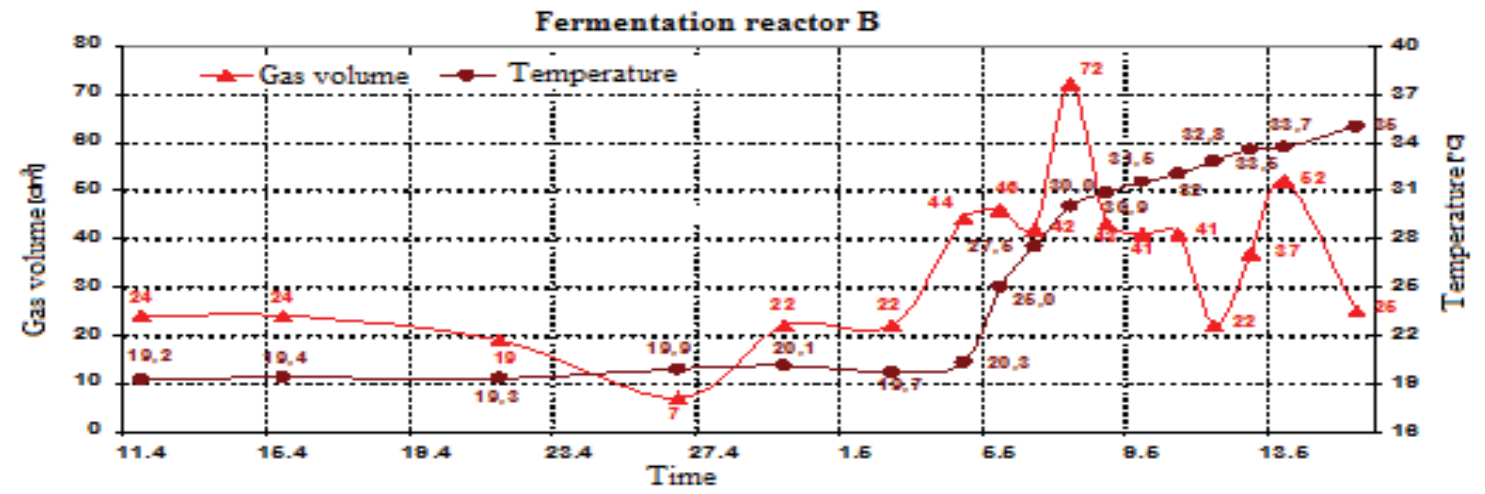

Figure 2: Course of temperature during fermentation and gas production in the reactor $\mathrm{B}$

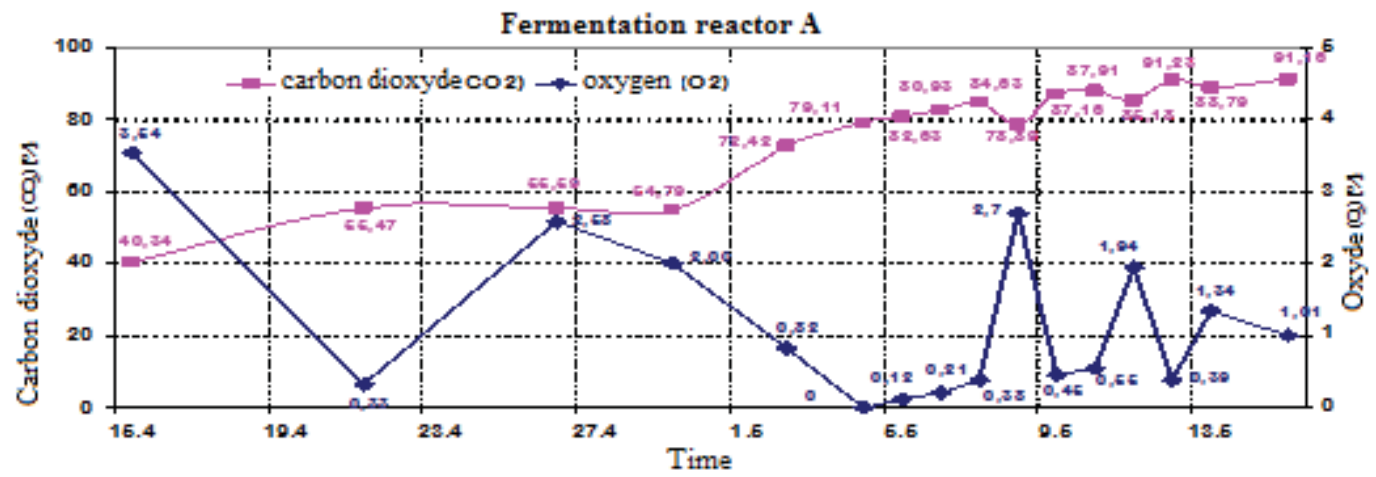

Figure 3: The content of carbon dioxide and oxygen in the reactor $A$

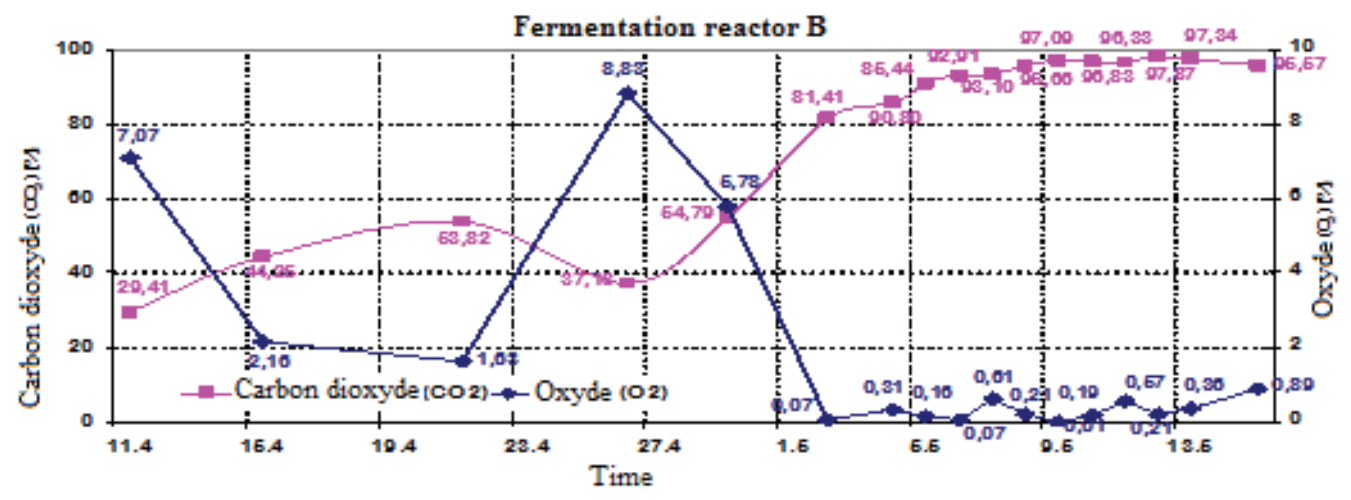

Figure 4: The content of carbon dioxide and oxygen in the reactor B 


\section{CONCLUSION}

the start of the fermentation process has shown that distrust of dry fermentation is quite justified. Run the fermentation process is not easy, as well as its maintenance. In our case the problem was that initially it was not possible to heat the reactors. When this is resolved, gas production has increased, but after a few days was again declining. Bacteria inside the reactor are very sensitive to temperature changes and temperature rise of about $2{ }^{\circ} \mathrm{C}$ per day could cause the cessation of fermentation processes. It shows, that very important is the pressure in fermentation reactors. High gas pressure inside the fermenting reactor negative effect on methane bacteria and slows down the formation of methane. At present, after the new inoculation was launched fermentation process again, at higher volume of methane.

\section{ACKNOWLEDGEMENT}

This article was created within the project VEGA 1/0258/09

\section{REFERENCES}

[1] Lábaj,Kapjor, Papučík, Z.: Alternatívne palivá pre energetiku a dopravu, Žilina, Georg, 2010 